\title{
Marketing of fish products
}

\begin{abstract}
Marketing of fish involves all the activities in the flow of fish or fish products from the farmer to the consumers. The target of marketing is usually to close the gap between the areas of fish scarcity and abundance with profit. There are certain characteristics and elements that are common with the marketing of fish products which demand peculiar skills for their operation. They include assemblage, storage, sorting, grading, packaging, labeling, storage and transportation. These operations are carried out by marketing agents like producers, fishermen cooperatives societies, wholesalers, retailers, vendors and consumers who are the key players in the marketing channels. The challenges in marketing of fish such as perishability of fish products, inadequate and poor processing facilities, poor quality fish products among others could be reduced by observing the basic marketing principles and factors that influence the buying and selling, demand and supply of fish products in the markets.
\end{abstract}

Volume 8 Issue 2 - 2019

\author{
Asogwa VC,' Asogwa JN² \\ 'Department of Agricultural and Home Science Education, \\ Michael Okpara University of Agriculture, Nigeria \\ 2Department of Zoology and Environmental Biology, Michael \\ Okpara University of Agriculture, Nigeria
}

Correspondence: Asogwa VC, Department of Agricultural and Home Science Education, Michael Okpara University of Agriculture, Nigeria, Email asovinchidi@yahoo.com

Received: August 17,2018 | Published: April 26, 2019

Keywords: marketing, element of marketing, packaging, labeling, marketing, marketing channels, challenges to marketing, market driving factors.

\section{Introduction}

The end of the production process in agriculture is marketing. Marketing is the act of gathering in a public places for buying and selling merchandise or farm products such as fish and fish products. Farmers frequently consider marketing of fish products as one of their major challenges in fish farming. This is because while the farmers are able to identify poor prices, lack of transport, lack of ready market, and high post-harvest losses as the challenges, they are often poorly equipped to identify potential solutions. Successful marketing requires learning new skills, new techniques and new ways of obtaining and using the information appropriately. Marketing is the point in which the farmer's products such as fish leave him with a return called income. Marketing of fish involves all the activities in the flow of fish or fish products from the farmer to the consumers. It includes various operations required to move the fish or fish products from the producer to the consumer. Marketing of fish also entails the buying and selling of fish by an individual who may not be a fish farmer. The person's target is usually to close the gap between the areas of scarcity and abundance. In this chapter, marketing of fish is centered on processed fish which were also referred to as fish products since that of live fish was handled in chapter five. The main feature of marketing fish is that it is the point at which the price of fish is determined by the parties involved such as the farmers and the middle men or/and consumers for economic return.

\section{Importance of marketing fish products}

The marketing of fish is important in the following ways.

1. It helps in determination of price for the fish products.

2. It is a means of earning income for the farmer. Marketing makes it possible for a farmer or marketer to recover the money spent on both fixed and floating capital during the production or purchasing process.

3. Marketing of fish prevents glut by locating and transporting them from area of surplus to the area of shortage. This process encourages farmers to sustain and expand their production as much as they can.

4. It makes the taste of the consumers known to the farmers or marketers about the fish to produce or purchase for sale. During marketing, one can research into the types of fish highly preferred by the consumers to embark on the specie.

1. It facilitates exportation of fish products to provide foreign exchange earnings and conservation for the farmer and the nation. In addition, it establishes international relationship with other countries of the world.

5. Marketing determines the forms in which fish should be processed, stored, sorted, graded and sold to consumers.

6. Through packaging, it makes fish attractive and appetizing to consumer to enhance sale.

7. Marketing of fish creates employment opportunities for the many people.

\section{Features of marketing of fish products}

These refer to the characteristics that are common with the marketing of fish products. The main features of marketing of fish products include the following.

1. It begins at the level of individual farmers who are the producers. The farmers rear and/or harvest fish from the water bodies and process them to certain level before they make it available to the market.

2. It ends with the consumers. They are the end user of fish products. They either eat it or transform it into another form that is completely different from fish products. For instance, some industries consume fish by extracting oil from it.

3. Producers (Fish farmers) are widely dispersed. Initially, fish 
farmers are found at the riverine areas but these days, they are widely scattered in the society because of rise in fish pond, tanks, cage and other means of producing fish.

4. Fish products are perishable and seasonal in supply. Irrespective of the processing and preservation method adopted, fish has a specific duration in which it can store with little or no loss in nutritional value. Beyond such period, the fish products get spoiled and wasted. Also, the quantity of fish products supplied to the market is not same all round the year, making it possible to have time of surplus and scarcity.

5. Institutional supports are limited. The level at which institutions can support in the supply of fish products to the market is very small to make a significant increase in the market. The quantity of fish products supplied to the market by organizations or institutions are very small; the bulk quantity of fish products in the markets is supplied by individual farmers ${ }^{1-10}$.

\section{Element of marketing fish products}

These are important components without which marketing of fish may not be successful. Apart from processing, the major elements of marketing fish include storage, sorting, grading, packaging, transportation and buying and selling.

1. Assemblage: This is the process by which a farmer or marketer gathers his fish products from different sources together. In this case, the farmer or buyer brings together all fish products to the same spot from different sources that may or may not be of same species or products of fish. The process is common with marketers like wholesalers who buy fish products in bulk more than what one farmer may supply to the market. Assemblage enables the farmer or marketer to take accurate record of his total fish products.

2. Storage: This is the manner in which processed fish is kept and the accommodation of such fish before sale. Dry fish products are better stored in cool and dry environment. Fresh fish are kept in freezer to control the temperature for the growth of spoilage organism in the fish. Large quantity of fish is usually stored in very big freezer commonly known as "cold room". Storage of fish product is important because it prevent over flooding of market with fish which may result in reduction of market prices.

3. Sorting: This is the process of categorizing fish products into groups using certain characteristics such as size, colour, specie, weight and so on. The sorting of fish products depends on the form in which they were processed. For instance, dry fish can be sorted into full or cut fish. This enables easy grading, handling and marketing.

4. Grading: This could be synonymous with fixing prices. It is the act of allocating prices to the fish products especially sorted fish. The grading of fish products is determined by the market demand and value. It is necessary that the farmer or the marketer carries out a market survey to ascertain the current market price before grading. This would prevent arbitrary grading or costing that may lead to loss or inability to sale. Grading enable the farmer to estimate prices of fish products.

5. Packaging: This is the process of putting and wrapping of fish products in a certain materials or containers such as bag, cans, nylons, cartons and so on. It is the loading of fish products into any of the containers in readiness for storage or sale. Packaging makes fish products attractive for marketers or consumers and also aids handling during transportation.

6. Labeling: This is the act of attaching a piece of paper, fabric or plastic to a bag, cans, nylons or cartons containing preserved fish to identify, describe or give instructions about the content. The paper, fabric or plastic is known as the label. Some label contains the price of the fish in the can, bag or container.

7. Storage: This is the act of keeping processed fish products especially dry fish in a room or warehouse for sometime before supplying them for sale. It involves the storage of fish products temporally before sales or export.

8. Transportation: This entails moving processed fish from farm or warehouse to the middle men or consumers who may be at the farm gate or market. In most cases, farmers sell their products at the farm gate; it is the responsibilities of the middlemen to move fish from the farm or processing plants to the consumers in the market. Fish products could be conveyed through any means of transportation, the most important thing is to provide required temperature that will stop the growth of spoilage organism. The distribution of processed fish in the tropic is largely by road transportation. The means of transportation ranges from wheel barrows, motorcycles, taxis, jeeps, pick-up vehicles, buses, trucks and lorries. This segment is a vital element in the distribution of fish from the processing village to wholesale markets and onward to retail outlets.

9. Advertisement: This is the act of publicizing or making fish products supplied to the market known to the public. It creates awareness to the public about the availability, quality, prize and other necessary important issues. This could be carried out through personal contact, radio, television, bulleting, newspapers among others.

10. Selling and buying: This is the process by which farmers or middle men exchange their fish products with money and middle men acquiring fish products from farmers by the marketers or consumers through payment. The farmers give out their fish products to the farmers through the process of selling while the middle men obtain fish products from the farmers through the process of buying. Therefore, selling and buying are interwoven and go together for fish products to move from one person or place to another. The buying and selling of fish products begins with the farmers while the chain ends with the consumers.

\section{Packaging of fish products}

It is necessary that the processed fish or fish products be packaged to easy marketing after processing. There are several ways of packaging, transporting and marketing of processed fish. There are almost as many traditional methods of processing fish as there are ways of packaging it. The materials used and the methods of packaging depend on the nature of the processed fish product and the reason for packing the product. The forms of fish which farmers can package are fresh and dry fish. The basic packaging materials common in the tropics include paper, cartons, sheets of metal, metal foils and plastics of different kinds and shapes. Despite the rapid growth in use of plastics and polyethylene, the use of paper and carton in packaging fish products does not decrease. For quality assurance, the suitability of packaging materials and methods are of great importance. This is because, if the requirements are not reached, all the efforts made during processing 
could be of little avail, resulting in serious economic losses and psychological stress for the farmer. The quality of fish delivered to processing plant or consumer greatly depends on handling during packaging, transportation and marketing. In order to maintain good quality of fish products during transportation, packaging materials made of suitable materials ought to be used. The qualities of good packaging materials include the following.

1. It should be made from a clean and non- poisonous material.

2. It should be non-staining, that is, it should not stain the fish after packaging.

3. The material should be of suitable size for the range of fish or fish products to be packaged.

4. The size should be convenient for manual handling for easy loading and off loading.

5. The size should be stackable, that is, the weight on top should not damage ones underneath.

In any case, the most important principle of packaging of processed fish products especially fermented ones is that the containers should be air-tight in order to develop and maintain the airless conditions required for good fermentation and storage. Irrespective of the materials and methods used in packing of fish, the aim is usually to:

1. protect processed fish from physical injury;

2. protect it from contamination with spoilage organisms

3. prevent it from spoilage for a certain period of time;

4. reduce the smell and the drip from the fish;

5. elongate the shelf life of the fish product;

6. make distribution easy;

7. enhance display of fish product for advertisement;

8. make the product attractive for the customers;

9. ease marketing of fish after processing; and

10. Enable the display of necessary information on the product for the costumers.

\section{Principles of packaging of fish products}

The following principles guide fish packaging in the tropics.

1. The pack should be such as to ensure that the product is properly protected from mechanical damage, contamination, leakage, desiccation, and excessive oxidation.

2. The fish units put into a container should be reasonably uniform in size.

3. The packaging material should not spare a flavour to or causes discolouration of the fish, or is itself discoloured by contact with the fish.

4. All the packaging material should meet the requirements of Public Health Regulations of the countries in the tropic.

5. Fresh fish should be packed in waterproof or vapour proof wrapping materials to avoid contamination.
6. Dry fish should be packaged in cool and dry materials.

7. The package should be marked clearly, legibly and indelibly on the immediate package or carton.

\section{Forms of packaging fish}

The forms of packaging fish products depend on the nature of processing. Farmers usually process fish into either fresh or dry fish. Although the materials used be same such as polythene bag and carton, but the method of packaging fresh fish differs from that of dry fish.

\section{Skills in packaging of fresh fish}

The skills in packaging fresh fish include the following.

1. Source polyethylene film or copolymer of ethylene and vinyl acetate that are already pre-made bags.

2. Sort fresh fish into groups of similar sizes after washing them.

3. Open the polyethylene film bag wide to fill it.

4. Arrange the sorted fresh fish horizontally in the bag to a desired quantity or amount.

5. Close the bag immediately to avoid entry of dirt.

6. Seal the bag using vacuum-packing with single, double or continuous chambers to remove air from the package.

7. Pump in a mixture of gases into the package immediately on removing the air from the package. The mixture of air should comprise $30 \%$ nitrogen, $40 \%$ carbon dioxide, and 30\% oxygen. Where fat fish are packaged, the oxygen should be replaced with nitrogen.

8. Insert the sealed polyethylene film bag of fish into a sizable carton.

9. Store the packaged fish at the temperatures lower than $30 \mathrm{C}$ because of C. botulinum hazard.

In addition, vacuum-skin packaging is widely used for packing smoked fish. In this process, the wrapper (polyethylene film) is heated and wrapped over the product, the film moulding completely to the product shape and sealing the product completely, forming an extra skin.

\section{Skills in packaging of dry fish products}

The skills in packaging dry fish include the following.

1. Source different sizes of carton to package dry fish.

2. Sort dry fish into groups of similar sizes.

3. Open the carton wide to fill it.

4. Arrange the sorted dry fish horizontally or vertically depending on the shape until a desired quantity or amount is reached.

5. Close the carton carefully to avoid entry of dirt.

6. Seal the carton using seal tape.

7. Store the sealed carton in a cool dry room.

\section{Labeling of fish products}

Labeling provides consumers with necessary information about the raw material used, method of preparation and form of consumption, 
shelf life of the packaged fish among others. However, packaging and labeling of packaged fish products by a farmer may not provide all the information needed such as nutritive and energetic values (kcal or $\mathrm{kJ} / 100 \mathrm{~g}$ or $100 \mathrm{ml}$ ), percentage of recommended daily intake of protein, vitamin $\mathrm{A}$ and $\mathrm{C}$, iron, calcium, the amount of basic ingredients and nutritive compounds such like proteins, carbohydrates, fat, fibre, sodium and vitamin content. It is important that labeling of packaged fish by farmers, give information like:

1. Common name of the fish in accordance with accepted scientific taxonomy such as Annex C.

2. method used in processing the fish like smoking, salting, drying, smoke-drying, salt-smoking, brine-smoking among others;

3. number of fish in the cartons;

4. net weight of the contents distinctly printed;

5. shape of the fish such as bent, cut or otherwise;

6. Batches of product. This makes it easier to withdraw the batch from commodity turnover in the case of health hazard; and

7. Full name and business address of the processor or packer.

The labeling of fish products without detailed standards, the existence of limited regulations concerning wholesomeness, sanitary conditions for production and trade of food products characterize the market economy of most countries in the Tropics. Here, the problem of labeling is of a particular importance. Regulations, in this regard, are very detailed and are aimed at protecting the health of the consumer and providing the best information. These requirements enable the consumer to decide which products to buy. A label placed on the product should inform the consumer about the raw material used, method of preparation and form of consumption, shelf life, etc.

\section{Marketing agents of fish products}

Agents refer to particular individuals who provide particular services for another. Fish marketing agents are those who provide services such as producing, processing, sorting, packaging, labeling, transporting, storing and selling to the buyers. They are mediators between the fish farmers and the consumers. They convey fish products through buying and selling of the products from the farmers to the buyers who may be marketers or consumers. The agents see to the transportation, storage and distribution of fish products from the farmers to the buyers in the same or different place. They convey fish products from the area of abundance to the area of scarcity in same or different country. The agents involved in marketing of fish products include producers, fishermen cooperatives societies, wholesalers, retailers, vendors and consumers.

1. Producers: These are farmers who supply fish products from either natural or artificial ponds. They include those farmers who only harvest fish from the natural waters such as stream, lagoon, river, ocean and sea and those who supply fish from their artificially established ponds. The former group of farmers is sometimes referred to as folk farmer but just like the early men who are fruit gatherers and hunters, they are farmers. Their functions in the channel are to harvest and supply fish products to buyers in the market. Some of the fish farmers go to the extent of processing their products before supplying them to the market. The problem of the producers is that they lack processing, storage and transport facilities and may suffer increased loss of fish especially in cultured fish.

2. Auctioneer: This is a person who offers goods such as fish products to buyers for pricing and sells it to the highest bidder. The auctioneer is the first intermediary in fish product marketing channel in most tropical countries. The fisherman takes his catch to auctioneer, who auctions it to various buyers/traders at the landing centre or along the road. The auctioneer sometimes pays up front to the fisherman to secure the right to auction his fish at any time of catch. Auctioneers, depending on the bargaining power of the farmers, charge $5-10 \%$ of sales value as their commission from the fishermen. There is a virtual barrier to the entry into this profession, which is mainly inherited by the local fishermen community or associations across all the coastal states in the tropical countries. In freshwater fish marketing, the auctioneer employs or sources fish through a commission agent who purchases fish from landing

3. Fishermen Cooperatives Societies: These are group of fishermen who combines or pool their resources together with the view of making profit through marketing of fish products. Each of the members is qualified to participate in the management of the society but the dividends are shared according to the level of individual's financial contribution. They buy fish products in large quantity and make them available to the members and other wholesalers or retailers for sale at reduced prices. They cushion the effect of low capital, high cost of transportation services, inadequate storage facilities and other market risks for the wholesalers and retailers as they distribute fish to their members and sometimes on credit to be paid back by installment. They stimulate competition among members in marketing of fish as they grant loan to members. In any case, poor management, lack of marketing strategy and well-defined lending policy, and absence of vertical integrations of different activities were found to be the reasons for losses in the fishermen co-operative societies. This agent is liable to poor management and financial misappropriation due to bias, religious or tribal politics that may bring in incompetent leadership to handle the affairs of the society.

4. Wholesalers: These are group of agents who buy fish products in large quantities from the producers (farmers) and sell it in small quantities to the retailers or consumers. They buy fish in bulk from producers or auctioneers and sell it to retailers or other traders. They also carry out value additions such as processing, sorting, grading, cleaning, icing, packing, labeling, transportation and storage of fish before sale. They pass information from retailers to the producers and vice versa. In the case of farmed fish, wholesalers act as a commission agent to whom the fisher/ farmers sell their produce. The wholesalers take up the risk of selling the fish and therefore keep a higher margin as compared to auctioneers. Ice, packaging and transportation form the largest share of the wholesaler's costs. The disadvantages of wholesalers in the marketing system are that they exploit both producers and retailers, hoard fish products to create artificial scarcity and inflate prices of fish products.

5. Retailers: These agents buy fish products in large quantities from the wholesalers or producers and sell it in small quantities directly to the consumers, the end users. The retailers sell fish products directly to consumers. They purchase fish products from the wholesalers based on the level of local demand and their 
purchasing power. They carry out maximum value addition such as grading, cleaning, icing, packaging, displaying and dressing in line with the interest and demand of the consumers. The retailers buy fish products mainly from the wholesaler, but in several cases, groups of retailers participate in the auction process for buying fish products directly from the auctioneer. They pass information from wholesalers to the consumers, make fish products readily available to consumers and give credits to some consumers who may be in need. Retailers keep a marketing margin of about $20 \%$ with lots of variation across the country. Labour involved forms the largest share of the retailer's costs. The disadvantages of this group of agents are that they create artificial scarcity and inflate prices of fish products for the consumers. The major challenge in this agency is loss due to decay or spoilage and pilfering.

6. Vendors: These are mobile agents of fish marketing that sell fish directly at the door steps of the consumers. Most fish vendors in tropic are women and they also carry out value addition by sorting, grading, cleaning and icing fish or oiling of dry fish products. They participate in auction directly in some of the states in the tropics. This group of marketers saves consumers the energy and cost of going to market to purchase fish but they may inflate the price arbitrarily. They are forced to sell all the produce on a given day because they don't have the capacity to store or preserve the fish. The major costs to vendors are on ice and transportation in addition to little capital involvement.

\section{Marketing channels of fish products}

Marketing channels refer to means or outlet through which fish products pass from the farmers to the final consumers. The marketing channels include:

1. Local Market: This is a place near home of the farmers where sellers and buyers. In this place, the fish farmers have contact with buyers who sometimes come to their farm to bid for their products. The buyers save fish farmers the stress of transportation but puts them at a disadvantage in bargaining unless they have good knowledge of the current price in the market. The farmers may have a nice chance of obtaining full value of his fish products in an organized local market where many buyers and other farmers are present with adequate information of the current market prices.

2. Commodity Exchange Market: In this case, fish products traded on are never seen in the market. Through this marketing channel, buying and selling takes place by mail, fax or telephone call. This exchange market provides means of insurance for farmers and middlemen against risks and uncertainties. Farmers producing agricultural produce are scattered in remote villages while consumers are in semi-urban and urban areas. This produce has to reach consumers for its final use and consumption. There are different agencies and functionaries through which this produce passes and reaches the consumer. A market channel or channel of distribution is therefore defined as a path traced in the direct or indirect transfer of title of a product as it moves from a producer to an ultimate consumer or industrial user. Thus, a channel of distribution of a product is the route taken by the ownership of goods as they move from the producer to the consumer or industrial user.

3. Commission Agents and Brokers: These are specialists in buying and selling fish products for marketers and taking charge of the products on their behalf. They are sustained in the occupation by being paid a certain percentage of the price obtained from the purchase or sale. There is no specific percentage paid to the commission agents and brokers on each batch but it all depend on the bargaining power of the two parties. Their service enables the buyer or seller to have intimate information of the supply of fish products, requirements and prices in various markets. Sometimes, they buy fish products from the farmers and sell to the marketing boards or experts.

4. Exporters: These are people who buy fish products from commission agents or commercial fish farmers and send products to other countries for sale. They buy fish products in large quantity and send them to buyers or consumers in other countries where scarcity exist for them to make their profit. The exporters are intermediate between countries of abundance and scarcity thereby saving farmers the situation of glut and the consumers that of high cost and starvation.

\section{Skills in marketing of fish products}

The skills that could be adopted by farmers in marketing of fish products successfully include the following.

1. Survey the market to determine the size of fish products that buyers pay best price.

2. Sort fish products using sizes, colour, species and level of processing.

3. Package sorted fish in bags, paper cartoons or any other material of one's choice.

4. Grade packaged fish products using quantity and quality of fish products.

5. Label the packages appropriately to give clear instruction to the buyers or consumers.

6. Fix prices for each packaged fish products based on market survey or demand.

7. Transport packaged fish products to market or showcase them for sale at better price.

8. Advertise the fish products locally and internationally through media or middlemen to attract buyers.

9. Sell fish products to effective buyers at an agreed price with evidence such as receipt.

10. Keep appropriate records of sales of fish products for sustainability, expansion and future references.

11. Calculate the expenditure on and income from the fish products to balance the profit or loss account.

\section{Challenges to Marketing of Fish Products}

Challenges here are situations facing marketing of fish products which need great mental or physical effort of the agents in order to carry out the operations successfully. These situations test the abilities of all the marketing agents of fish products in one way or the other. The challenges include the following.

1. Perishability of fish products: Naturally, fish products are high perishable and can easily get spoiled within a very short time if 
not handled properly. This condition forces the farmers and other marketing agents to sell of their products as soon as possible.

2. Inadequate and poor processing facilities: Some of the facilities needed to process the products to a form that will enable the marketing agents to store it safely within a short time are not readily available and not adequate where available.

3. Poor quality fish products: The ability of fish products to store for a long time depends on the quality of processing. Some of the products supplied to the market by the farmers are contaminated and not well processed because they hasten to remove the products from their hand before they get damaged. Poor quality fish products spoil during marketing as the products move from one agent to another.

4. Inadequate storage facilities: Fish products especially captured fish take some time to be supplied by farmers which makes its supply seasonal. This means that fish products have to be stored to make it available all the period of the year. But storage facilities that could be used for fish products are inadequate among the marketing agents. This puts the agents under pressure to buy fish in a manageable quantity that can be disposed off before it gets spoiled.

5. Inadequate transportation system: This involves road and vehicles used for transportating fish products. The poor road net works and scarcity of haulage vehicles in most countries in the tropics make it difficult to move fish products from the area of production to the area of consumption, abundance to scarcity. Poor road system increases the cost of buying and selling fish products, reduces payments to farmers and increases prices to consumers. It also results in loss of fish products along the marketing chain.

6. Small quantity supply: Most of the producers of fish (farmers) are peasants and engage in small scale of production, as a result, they only supply small quantity to the market. This forces the marketing agents to buy fish in small quantity irrespective of their capital, hence increase the cost of transporting the fish products each time of purchase.

7. Poor capital: Some marketing agents started with very little capital which makes it difficult for them to purchase large quantity of fish products, store and transport the products. Poor capital makes it difficult for wholesalers to buy large fish products of farmers who may want them to pay for their fish before they get matured for sale. It also hinders retailers from buying enough and selling their goods to the consumers on credit to keep them.

8. Inadequate marketing infrastructure: Most markets especially in the village lack infrastructure such as pipe born water, cold rooms, electricity, telephone services that are necessary for processing and preservation of fish products to avoid spoilage.

9. Inadequate marketing information: Most farmers and other marketing agents do not normally get adequate information on the current market prices of fish products in their store, as such, they sale of their products or goods with little or no gain. Some lack marketing facilities like telephone, internet gadgets that could enable them to buy and sell their fish products without actually travelling to the market or having contact with the customer.

10. Instability of market prices: The prices of fish products are unstable and have never remained same for one full year without any fluctuation. The worst of it is that the fluctuation is hardly forecast or determined by the marketing agents beforehand. The instability of the prices is advantageous and disadvantageous depending on the fish products and the agents involved. For instance, decrease in fish products may discourage farmers from increasing the scale of their production which will affect the quantity of their supply later. In the same vein, decrease in price will encourage other marketing agents such as wholesalers to buy more fish products from the farmers and the retailers from the wholesalers but will discourage supply by all the agents including farmers unless otherwise forced by other unforeseen factors.

11. Lack of uniform measurement: There is no uniform measure or standard for determining the size, quantity or amount of fish products to be sold at what prize. The prices are decided by each agent depending on market situations such as availability of the product, season of the year, location of the market among others. This is why the prices of fish products differ widely among countries in the tropics and states or cities within a particular country.

12. Policy in Marketing of Fish Products: Marketing of fish products needs to be carried out within a supportive policy, legal, institutional, macro-economic, infrastructural and bureaucratic environment. The marketing agents and others cannot make investments in a climate of arbitrary government policy changes, such as those that restrict imports, exports and internal produce movement. The marketers find it difficult to function if their trading activities are hampered by excessive bureaucracy. Inappropriate law can interfere and reduce the efficiency of the market, increase the costs of running business and retard the development of a competitive private sector. Weak support institutions, such as agricultural extension services, municipalities that operate markets inefficiently and export promotion bodies, can be particularly destructive. In addition, the ever-present challenge of corruption can seriously influence marketing of fish products efficiency in many countries in the tropics by increasing the transaction costs faced by agents in the marketing chain.

13. Presence of marketing agents: The agents in marketing of fish products are the auctioneer, wholesaler, retailer and the vendor. These agents have great impact on the sources of marketing, costs such as transport, commission charges and market margins received by the intermediaries such as trader, commission agent, wholesaler and retailer. They decide the price to be paid by the consumer and share of it received by the farmer/producer. An agent or a channel is considered good or efficient if it makes the produce available to the consumer at the cheapest price and also ensures the highest share to the producer. The cost of fish products is directly proportional to the number of the agents involved in the market chain as each agent involved will increase the cost to make profit. So the smaller the number of agents involved in a chain, the lower the cost of the fish products. The stronger the marketing agencies, the better for the marketers and consumers. The agents involved in marketing of different fish products are summarized thus. ${ }^{11-17}$

I. Producer (fish farmer) - fishermen cooperative society - wholesaler - retailer - consumer.

II. Producer (fish farmer) - fishermen cooperative society/wholesaler - processing industries - wholesalers - retailer - consumer 
III. Producer (fish farmer) - fishermen cooperative society - retailer - consumer

IV. Producer (fish farmer) - wholesaler - retailer - vendor - consumer

V. Producer (fish farmer) - wholesaler - retailer - consumer

VI. Producer (fish farmer) - retailer - consumer

VII. Producer (fish farmer) - consumer

\section{Market driving factors of fish products}

These are factors that control or influence the buying and selling of fish products in the markets. Such factors include population growth, demand for fish protein among others.

1. Population Growth: All things being equal, the demand for fish products will increase with population growth and urbanization. The world population which is now at about 6.9 billion will reach more than 7.5 billion by 2020 . It was reported by FAO that wild fish catch has stayed constant for several years while world population and average demand for fish products keeps increasing. This has caused an imbalance in supply and demand in the international market which commercial aquaculture is currently filling part of the gap, but yet cannot fully satisfy the demand.

2. Demand for Fish Protein: The recommendation and demand for fish protein and white-fleshed fish tends to grow with improved understanding of the importance of fish to good health. People have recognized the effect of shift from traditional diet and are now paying more attention to healthy food such as fish, hence, the current rise in the overall global demand of fish.

3. Advancement in Fish Farming Technologies: Recently, there has been rapid advancement in the fish farming technologies especially in the areas of spawning. At present, breeding, hatchery and farming technologies have been resolved and provide a good foundation for intensive fish culture in ponds, tanks, cages which supplies fish products round the year. For instance, a white-fleshed fish, precisely tilapia has become a wide market appeal.

4. Restriction on Captured Fish: There are rules and regulations on Marine resources exploitation that is being implemented around the world. As a result, capture fish products have not generally increased in recent years. In addition to restriction by quota, cod as a popular white fish product, has been on the decline, which increases a market opportunity of other fish products.

5. Increase in Acceptance of TILAPIA: Tilapia is gaining higher acceptance by more people and markets as they look for whitefleshed fish substitute products. This makes its market to increase proportionally with rise in acceptance globally. Meanwhile, Tilapia aquaculture has clear competitive advantages compared to other farmed fish reasoning from technological, cost and level of inputs perspectives.

\section{Conflicts of interest}

The authors declare that there are no conflicts of interest.

\section{References}

1. Abolagba OJ, Nuntah JN. Survey on cured fish processing, packaging, distribution and marketing in Edo and Delta states. International Research Journal of Biotechnolog. 2011;2(5):103-113.

2. Acre LA, Igbokwe EM, Asadu CLA, et al. Coprehensive Certificate Agricultural Science for Senior Secondary Schools. University Press Plc. 2010 .

3. Agbebi FO. Salient Issues in Fish Marketing System in Nigeria. Journal of Environmental Issues and Agriculture in Developing Countries. 2010;2(1):94-205.

4. European Bank for Reconstruction and Development. Sub-sectoral Environmental and Social Guidelines. Fish Processing. 2009.

5. FAO. Handling of fish and fish products. Fisheries and aquaculture department. Rome. 2005.

6. FAO. Preservation techniques. Fisheries and aquaculture department Rome. 2005.

7. International Finance Corporation (IFC). Environment, Health \& Safety Guidelines. Fish Processing. 2007.

8. Ita EO. Principles and Practices of Integrated Commercial fish farming in Nigeria. Fisheries Research. 1980.

9. Iwena OA. Essential Agricultural Science for Senior Secondary Schools Tonads Publishers Limited. 2002.

10. Madugu, A. J. \& Edward, A. Marketing and Distribution Channel of Processed Fish in Adamawa State, Nigeria. Global Journal of Management and Business Research. 2011;11(4):21-26.

11. Oluborode GB, Adelowo EO, Unogwu A. Processing and packaging of smoked clarias gariepinus in Niffr. Standard Scientific Research and Essays. 2013;2(2):11-15.

12. Oparinde LO, Ojo SO. Structural Performance of Artisanal Fish Marketing in Ondo State, Nigeria. American Journal of Rural Development. 2014;2(1):1-7.

13. Osarenren CO, Ojor AO. Marketing analysis of smoke-dried fish in Etsako East Local Government Area of Edo State, Nigeria. Net Journal of Agricultural Science. 2014;2(3):104-106.

14. Southern Regional Aquaculture Center. Processed Catfish. Product Forms, Packaging, Yields and Product Mix. SRAC Publication. 1989:184.

15. UK Health and Safety Executive. Priorities for health and safety in the Fish Processing Industry. Food Sheet. 1997:16 p.

16. United Nations Development Fund for Women. Fish processing. Food Technology Source Book Series (UNIFEM) Series, 1993:137-138.

17. Zohar I, Dayan T, Galili E, et al. Fish processing during the early Holocene: a taphonomic case study from coastal Israel. Journal of Archaeological Science. 2001;28:1041-1053.

\section{Acknowledgments}

None. 